\title{
Photochemical formation of labile organic matter from two components of dissolved organic carbon in a freshwater wetland
}

\author{
Nasreen Bano*, Mary Ann Moran, Robert E. Hodson \\ Department of Marine Sciences, University of Georgia, Athens, Georgia 30602-3636, USA
}

\begin{abstract}
We studied the photoproduction of biologically labile compounds from 2 chemically defined fractions of dissolved organic matter (DOM) and whole (unfractionated) DOM from an acidic freshwater wetland (Okefenokee Swamp, Georgia, USA). Water samples were collected in summer (July 1995) and winter (February 1996), and for the winter sample, DOM was separated into humic substances and 'non-humic' compounds by fractionation on an XAD-8 resin. Following exposure in quartz flasks to either natural or simulated sunlight, bacteria were found to utilize as much as $300 \%$ more organic matter in irradiated whole DOM and chemical fractions compared to non-irradiated counterparts. Previous studies have shown that humic substances, which have strong absorption in the UV region of sunlight, are important sources of biologically labile photoproducts. We now demonstrate that compounds outside this operational definition are also sources for labile photoproducts, and that production rates on an absorbance-normalized basis can be equivalent for the humic and non-humic components of DOM. Humic substances were nonetheless calculated to be the primary source of biologically labile photoproducts in these samples, based on the fact that they absorbed most $(>85 \%)$ of the sunlight. Exposure of DOM fractions to sunlight for the equivalent of 7 h of noontime sun (at $34^{\circ} \mathrm{N}$ latitude) resulted in the bacterial utilization (over a subsequent $4 \mathrm{~d}$ period) of up to $6 \%$ of the humic substances pool (compared to $1.5 \%$ for non-irradiated controls), and $11 \%$ of the non-humic compounds (compared to $3 \%$ for non-irradiated controls).
\end{abstract}

KEY WORDS: DOM · Humic substances $\cdot$ Photodegradation - Bacterial secondary production

\section{INTRODUCTION}

Studies of the biological turnover of dissolved organic matter (DOM) in aquatic environments are often hampered by the extreme heterogeneity of the compounds that make up this important carbon reservoir. One approach to dealing with DOM heterogeneity is to subdivide it into 2 simple chemical fractions: compounds that fit the operational definition of humic substances and those that do not. The humic substances fraction is defined based on adherence to a hydrophobic (XAD-8) resin at $\mathrm{pH} 2$, and is primarily made up of colored polyelectrolytic acids. Humic substances account for about $50 \%$ of the DOM in most freshwater environments (Thurman 1985), with contributions reaching $80 \%$ in

•E-mail: nasreen@arches.uga.edu some colored lakes and wetlands. The remainder of the DOM, those compounds that do not fit the operational definition of humic substances, we refer to here as 'nonhumic' compounds. This fraction contains small, readily identifiable molecules (amino acids, sugars, carboxylic acids; Thurman 1985) as well as the hydrophilic acid fraction of DOM, a heterogeneous mixture of compounds that are smaller and more polar than humic substances (Aiken et al. 1992).

Previous studies have addressed the issue of the biodegradability of these DOM fractions. Humic substances are generally recognized as biologically recalcitrant, and while it can be demonstrated that humic substances support measurable bacterial activity in humic-rich systems, generally less than a few percent of this pool is degraded by natural bacterial communities on time scales of weeks to months (Tranvik 1988, 
Moran \& Hodson 1990, Bano et al. 1997). By contrast, the non-humic fraction of DOM includes a number of compounds recognized as important bacterial substrates in aquatic environments, such as sugars and amino acids (Wright \& Hobbie 1966, Azam \& Hodson 1977), although they are present in low concentrations. Less is known about the bioavailability of the hydrophilic acids which numerically dominate the non-humic fraction. Non-humic compounds as a group, however, can be expected to have a higher average biodegrada bility than humic substances (Moran \& Hodson 1990).

Recently, there has been growing recognition of the role of photodegradation by natural sunlight as an important factor controlling biological degradation of DOM. Photodegradation has been found to change the size and chemical characteristics of DOM (Strome \& Miller 1978, Amador et al. 1989, Backlund 1992, De Haan 1993, Allard et al. 1994, Miller \& Zepp 1995), and to release small, biologically labile compounds from the more refractory DOM molecules (Kieber et al. 1989, 1990, Wetzel et al. 1995, Bushaw et al. 1996, Lindell et al. 1996, Moran \& Zepp 1997). To this point, it is the humic substances fraction of DOM that has served as the focus of many studies of sunlight enhanced biological degradation of DOM, both because of the dominance of humic compounds in many freshwater systems and because of their strong absorption in the ultraviolet (UV) region of sunlight (Kirk 1994). Photoreactions of humic substances have been found to yield a number of bacterial substrates, including low molecular weight carbonyl compounds (Kieber et al. 1990, Wetzel et al. 1995), ammonium and other primary amines (Bushaw et al. 1996, Bushaw \& Moran unpubl.), and modified humic substances (Miller \& Moran 1997). The potential for compounds falling outside the operational definition of humic substances to yield biologically labile compounds through natural photoreactions has not yet been specifically explored.

In this paper we provide evidence for the photoproduction of biologically labile compounds from DOM from the Okefenokee Swamp, an acidic freshwater wetland characterized by very high DOC concentrations ( 35 to $50 \mathrm{mg} \mathrm{Cl}^{-1}$ ). We also demonstrate that nonhumic compounds from this system can be equally photochemically reactive on a absorbance-normalized basis, and thus that compounds outside the operational definition of humic substances can serve as a source of photolabile compounds in surface waters.

\section{MATERIALS AND METHODS}

Sample collection. Water samples were collected on July 14, 1995 (Expt 1) and February 2, 1996 (Expt 2) at the Suwanee River sill in the Okefenokee Swamp,
Georgia, USA. Particulate material was removed from the water by sequential filtration through a precombusted GF/F filter and $0.22 \mu \mathrm{m}$ pore size polycarbonate (Nuclepore) membrane filter using large Plexiglas filter holders (293 mm diameter). To minimize contamination, membrane filters were flushed with approximately $1 \mathrm{l}$ of Milli Q water and approximately $1 \mathrm{l}$ of sample water before filtrate collection.

Chemical fractionation of DOM. For the February sample, DOM in a 51 volume of filtered-sterilized water was fractionated into humic substances and non-humic compounds (Aiken 1985, Moran \& Hodson 1990). Water was acidified to $\mathrm{pH} 2$ with $6 \mathrm{~N} \mathrm{HCl}$ and then passed through a $2.2 \times 40 \mathrm{~cm}$ column of Amberlite XAD- 8 resin at a rate of $50 \mathrm{ml} \mathrm{min}{ }^{-1}$. Aquatic humic substances adhered to the hydrophobic XAD-8 resin, while more polar molecules (referred to as 'non-humic' compounds) passed through the column and were collected. The humic substances were eluted from the column in concentrated form with $200 \mathrm{ml}$ of $0.1 \mathrm{~N} \mathrm{NaOH}$ and desalted by pumping through a cation exchange resin (Bio Rad AGMP 50), and then were reconstituted in sterilized deionized water to their original concentration at the time of sample collection. The $\mathrm{pH}$ of both fractions (humic substances and non-humic compounds) was adjusted to the original value $(\mathrm{pH} 4)$ before use in bioassay experiments.

Irradiation of DOM. Whole DOM and fractions were checked for bacterial contamination by Acridine Orange Direct Counting (AODC; Hobbie et al. 1977) both before and after irradiation. Bacterial cells were scarce or absent in all samples. Expt 1 samples (whole DOM only) were placed in 21 round bottom quartz flasks and exposed to full natural sunlight for $6 \mathrm{~h}$ (10:00 to $16: 00 \mathrm{~h}$ ) in Athens, Georgia, on July 14, 1995. Water temperature inside the flasks was maintained at $22^{\circ} \mathrm{C}$ by a running water system. Expt 2 samples (whole DOM, humic substances, and non-humic compounds) were placed in 21 round-bottom quartz flasks and exposed to artificial sunlight (DSET Heraeus solar simulator) for $7 \mathrm{~h}$. The bottom of the flasks was immersed in ice during irradiation to maintain the temperature at approximately $20^{\circ} \mathrm{C}$, and flasks were swirled manually every $30 \mathrm{~min}$. The spectrum and intensities of artificial UV irradiance generated in the solar simulator were similar to those of natural sunlight and were equivalent to approximately $7 \mathrm{~h}$ of noontime sun at $34^{\circ}$ latitude in January (approximately $86 \mathrm{~mW}$ $\mathrm{cm}^{-2} ;$ Miller \& Zepp 1995). For both experiments, nonirradiated treatments consisted of foil-wrapped flasks.

Bacterial bioassays. A natural bacterial inoculum was obtained by filtering 3 to $5 \mathrm{l}$ of water sequentially through a precombusted GF/F filter and a $0.6 \mu \mathrm{m}$ pore size polycarbonate membrane filter to remove bacterivores and particulate material. Bacteria were then concentrated by filtration onto $0.2 \mu \mathrm{m}$ pore size poly- 
carbonate filters and resuspended in $200 \mathrm{ml}$ of sterilized deionized water. Bacterial recovery was 12 to $16 \%$ of the original community. In all experiments, bacterial concentrates were prepared immediately prior to inoculation. The initial bacterial concentration averaged $0.1 \pm 0.03 \times 10^{6} \mathrm{ml}^{-1}$, approximately $10 \%$ of the original concentration of bacteria in the samples.

After inoculation, each DOM sample was subdivided and treatments were established as follows: no further manipulation ( $\mathrm{C}$ treatment), amendment with inorganic nitrogen to a final concentration of $60 \mu \mathrm{M} \mathrm{NH} \mathrm{NH}_{4} \mathrm{NO}_{3}$ ( $\mathrm{N}$ treatment), and amendment with both nitrogen and phosphorus to a final concentration of $60 \mu \mathrm{M} \mathrm{NH} \mathrm{NO}_{4}$ and $10 \mu \mathrm{M} \mathrm{KH} \mathrm{PO}_{4}$ ( $\mathrm{N}$ plus $\mathrm{P}$ treatment). In Expt 1 . an additional treatment was established for nonirradiated DOM by amendment with glucose alone (G treatment) to a final enrichment of $250 \mu \mathrm{M} \mathrm{C}$ (3 $\mathrm{mg}$ $\mathrm{C}^{-1}$ ). In Expt 2, an additional treatment was established for both irradiated and non-irradiated samples by amendment with inorganic phosphorus alone to a final concentration of $10 \mu \mathrm{M} \mathrm{KH}_{2} \mathrm{PO}_{4}$ (P treatment). All treatments were run in duplicate in $250 \mathrm{ml}$ Pyrex flasks, which were covered with aluminum foil caps and incubated in the dark at room temperature $\left(21^{\circ} \mathrm{C}\right)$ with gentle stirring. Over the next $96 \mathrm{~h}$, subsamples were removed periodically from each flask to measure DOC concentration, bacterial production, bacterial abundance, and bacterial biovolume.

DOC measurements. DOC concentrations were determined by high temperature catalytic oxidation using a TOC-5000 (Shimadzu) with a 4 point potassium biphthalate calibration curve. All measurements were carried out in triplicate.

Bacterial carbon production. Bacterial production was estimated from rates of ${ }^{3} \mathrm{H}$-leucine incorporation into the protein fraction of bacterial biomass (Kirchman et al. 1985, Smith \& Azam 1993). Triplicate subsamples from each flask $(1.5 \mathrm{ml})$ were placed in $2 \mathrm{ml}$ microcentrifuge tubes and amended with $20 \mathrm{nM}$ (final concentration) of ${ }^{3} \mathrm{H}$-leucine (specific activity: $173 \mathrm{Ci}$ $\mathrm{mmol}^{-1}$ ). Preliminary studies investigating saturation kinetics of leucine uptake over a concentration range of 10 to $50 \mathrm{nM}$ consistently indicated saturation at $20 \mathrm{nM}$ and above. An additional control tube received $89 \mu \mathrm{l}$ of $100 \%$ trichloroacetic acid (TCA) prior to the addition of ${ }^{3} \mathrm{H}$-leucine. After a $1 \mathrm{~h}$ incubation in the dark at room temperature, $89 \mu \mathrm{l}$ of $100 \%$ TCA was added to the live samples. Contents of the tubes were centrifuged at $14000 \times g$ for $10 \mathrm{~min}$. The supernatant was aspirated away and the pellet washed twice with $5 \%$ TCA and once with $80 \%$ ethanol. Liquid scintillation cocktail (1.5 ml; Packard Opti-fluor) was added to the tubes, which were placed inside $20 \mathrm{ml}$ glass scintillation vials and radioassayed in a Beckman LS 6500 liquid scintillation counter. Bacterial protein produc- tion and bacterial carbon production were calculated according to Simon \& Azam (1989) assuming 2-fold isotope dilution.

Bacterial abundance and biovolume. Bacteria were enumerated in formalin-preserved samples by AODC using an Olympus BH-2 epifluorescence microscope. Volume measurements were made on an average of 100 cells per filter using an image analysis system (Microcomp Inc.) calibrated with $1.7 \mu$ m fluorescent latex beads (Polysciences Inc.). Average cell size was multiplied by average cell number to calculate total biovolume, and biovolume measurements were converted to biomass by assuming a conversion factor of $0.22 \mathrm{~g} \mathrm{C}$ $\mathrm{cm}^{-3}$ (Bratbak \& Dundas 1984). The difference in bacterial biomass accumulation between irradiated and non-irradiated treatments was used as a measure of photoproduction of biologically labile organic matter.

Absorptivity and light screening corrections. Absorbance of the samples was measured on a Beckman DU 70 spectrophotometer; samples were diluted 1:1 with distilled/deionized water prior to absorbance measurements when necessary. For Expt 1, absorbance was measured prior to irradiation. For Expt 2, absorbance was measured both prior to and after irradiation. Absorption coefficients at $350 \mathrm{~nm}\left(a_{350}\right)$ were calculated as: $a_{350}=A_{350} \cdot 2.303 / b$, where $A_{350}$ is the absorbance of the sample at $350 \mathrm{~nm}$ and $b$ is the path length of the cuvette in meters (Miller 1998). Absorptivity values were used to normalize photoproduct formation rates to the amount of sunlight absorbed by the samples, as has been done previously for carbon gas photoproducts of DOM (Valentine \& Zepp 1993, Miller \& Zepp 1995). We chose $350 \mathrm{~nm}$ as the wavelength for absorptivity normalization because available action spectra indicate that this wavelength is at or near the peak efficiency of DOM photoproduct formation (Moran \& Zepp 1997).

Differences in DOC concentration and color between the humic and non-humic fractions resulted in different average light exposure for the 2 fractions during irradiation, with significantly more self-shading occurring in the humic substances flask. To correct for the effect of light screening on estimates of photoproduction of utilizable organic matter, we calculated the light screening factor using the derivations of Zepp (1982) as follows: $\left(1-\mathrm{e}^{-a_{350} \cdot \text { path length }}\right) /\left(a_{350} \cdot\right.$ path length), where path length is the average distance light traveled through the solutions during irradiation in the $2 \mathrm{l}$ quartz flasks (approximately $0.07 \mathrm{~m}$ ).

\section{RESULTS}

To examine the effects of exposure to sunlight on the availability of DOM to bacteria, we followed bacterial 
growth (as instantaneous rates of bacterial carbon production and as biovolume accumulation) in batch culture experiments established with irradiated and nonirradiated DOM fractions which had been amended with various combinations of inorganic nutrients. The percent change in bacterial parameters over that measured in the control was calculated according to the following formula: \% change = (treatment control) $\cdot 100 /$ control.

\section{Expt 1}

Bacterial production rates were similar for the $C, N$, and $\mathrm{N}$ plus $\mathrm{P}$ treatments for non-irradiated DOM (Fig. 1a). Addition of glucose resulted in increased bacterial production relative to the other non-irradiated treatments, suggesting that carbon was the primary factor limiting bacterial growth in non-irradiated whole water. Following exposure to sunlight, the carbon component of the DOM was more accessible to bacteria (Fig. 1b). Production integrated over the entire incubation period (96 h) was enhanced by $34 \%$ (C treatment), $63 \%$ ( $\mathrm{N}$ treatment), and $74 \%$ ( $\mathrm{N}$ plus $\mathrm{P}$ treatment) relative to that in non-irradiated samples. Bacterial biovolume data likewise indicated a similar amount of bacterial growth in all non-irradiated samples regardless of nutrient treatment (Fig. 1c) as well as enhanced growth following irradiation (Fig. 1d).
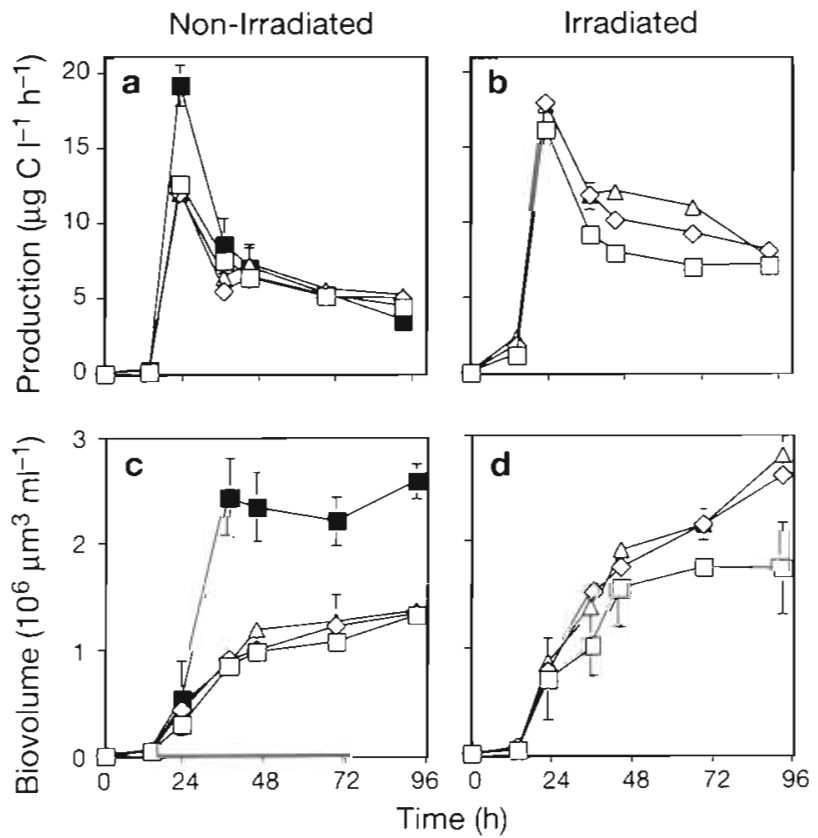

Fig. 1. Rates of $(a, b)$ bacterial secondary production and $(c, d)$ bacterial biomass accumulation in Expt 1 . Whole DOM was amended with $N(\diamond), N$ plus $P(\Delta)$ or glucose $(\square)$, or was not amended ( $\square$ ). $n=2, \pm 1 S D$

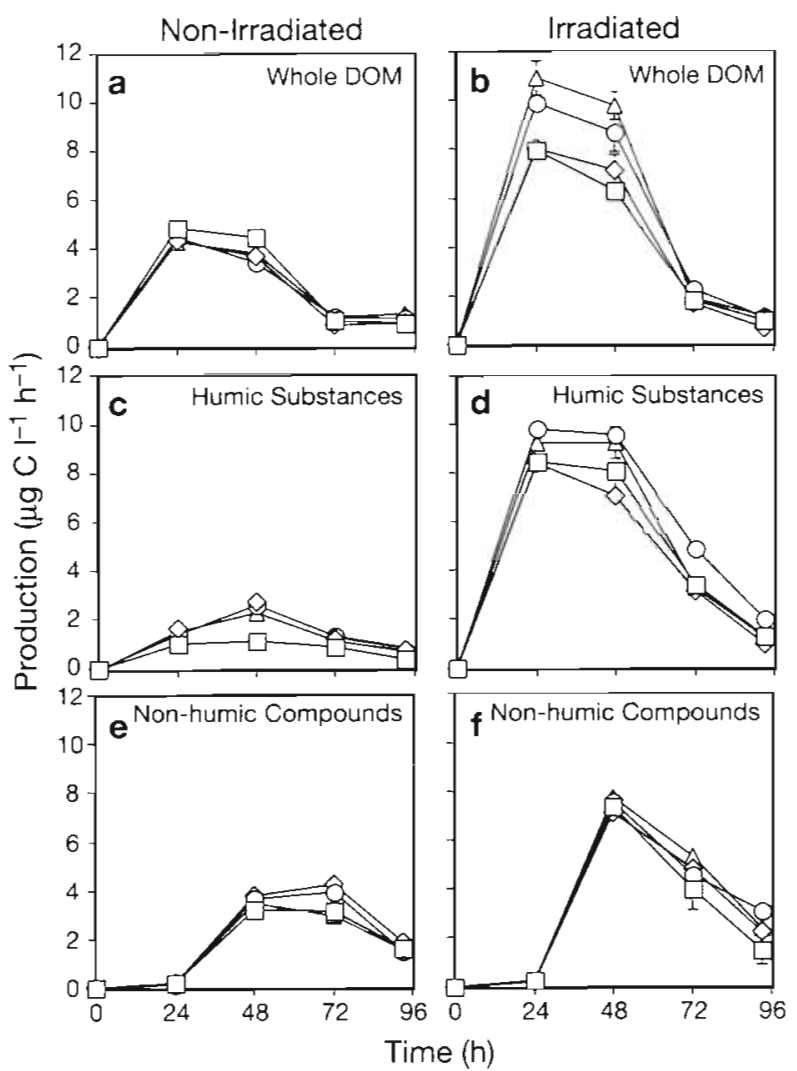

Fig. 2. Rates of bacterial secondary production in Expt 2. Whole DOM, humic substances, or non-humic compounds were amended with $N(\diamond), P(O), N$ plus $P(\Delta)$, or were not amended $(\square) . n=2, \pm 1 S D$

In the irradiated treatments, maximum biovolume accumulation was enhanced 30\% (C treatment), $94 \%$ ( $\mathrm{N}$ treatment) and $104 \%$ ( $\mathrm{N}$ plus $\mathrm{P}$ treatment) over the non-irradiated controls.

\section{Expt 2}

Bacterial production rates in all non-irradiated whole DOM treatments ( $C, N, P, N$ plus $P$ ) were similar (Fig. 2a), again suggesting carbon quality limitation rather than nutrient limitation to bacterial growth. However, exposure of whole DOM to sunlight made the carbon component more accessible to bacteria, and resulted in phosphorus, rather than carbon, limitation (Fig. 2b). Integrated production (over 96 h) was enhanced an average of $65 \%$ in the 2 treatments without added $\mathrm{P}$ (treatments $\mathrm{C}$ and $\mathrm{N}$ ) and $118 \%$ in treatments with added $P$ (treatments $P$ and $N$ plus $P$ ) for irradiated whole water relative to non-irradiated counterparts. Similar results were observed for bacterial biovolume measurements (not shown), with exposure to sunlight increasing biovolume an average of $52 \%$ in the 2 treat- 
ments without added $P$ and $172 \%$ in the 2 treatments with added $P$ relative to non-irradiated treatments. Statistical analyses of treatments grouped according to $P$ status indicated significantly higher bacterial production $(p=0.021)$ and biovolume $(p=0.021)$ in the 2 treatments with $\mathrm{P}$ additions relative to those without (Mann Whitney $U$-test)

The humic substances fraction of the February sample likewise exhibited significant photochemical reactivity. Bacterial production on humic substances was consistently higher in irradiated compared to non-irradiated treatments (Fig. 2c, d). Integrated production (over $96 \mathrm{~h}$ ) was enhanced $332 \%$ (average of all treatments) in irradiated humic substances relative to non-irradiated counterparts. Similar results were observed for bacterial biovolume data, with $197 \%$ greater biovolume accumulating in treatments without added $\mathrm{P}$ and $287 \%$ greater biovolume accumulating in treatments with added $\mathrm{P}$ relative to nonirradiated (not shown). Differences between treatments with and without added $P$ were significant for the irradiated samples based on biovolume data ( $\mathrm{p}=$ 0.021 , Mann Whitney $U$-test), but not bacterial production data.

Bacterial production on non-humic compounds was also consistently higher in irradiated compared to nonirradiated treatments (Fig. 2e, f). Integrated production was enhanced $63 \%$ for irradiated non-humic compounds relative to non-irradiated treatments. Nutrient additions had no effects on measured bacterial production rates for either irradiated or non-irradiated treatments, suggesting carbon limitation of bacterial growth in both cases. Similar results were obtained for biovolume data, with irradiated treatments accumulating $143 \%$ more biovolume than non-irradiated treatments (not shown).

\section{Utilizable organic matter}

Concentration changes in the DOC pool were small relative to the total pool and could not be detected consistently by direct DOC measurements. Instead, bacterial yield (the difference between maximum and initial biomass) was used to calculate bacterial carbon utilization under nutrient-sufficient conditions ( $N$ plus $\mathrm{P}$ treatment). A bacterial growth efficiency of $22 \%$ was used in the calculations, based on previous studies of Okefenokee Swamp DOM (Bano et al. 1997); use of a single efficiency value assumes that irradiation did not affect growth yield. When normalized to initial DOC concentration (Fig. 3), bacterial utilization of nonirradiated whole DOM was $29 \mu \mathrm{g} \mathrm{C} \mathrm{mg} \mathrm{DOC}^{-1}$ (July sample) and $17 \mu \mathrm{g} \mathrm{C} \mathrm{mg} \mathrm{DOC} \mathrm{mol}^{-1}$ (February sample). Exposure to $7 \mathrm{~h}$ of sunlight increased utilization of

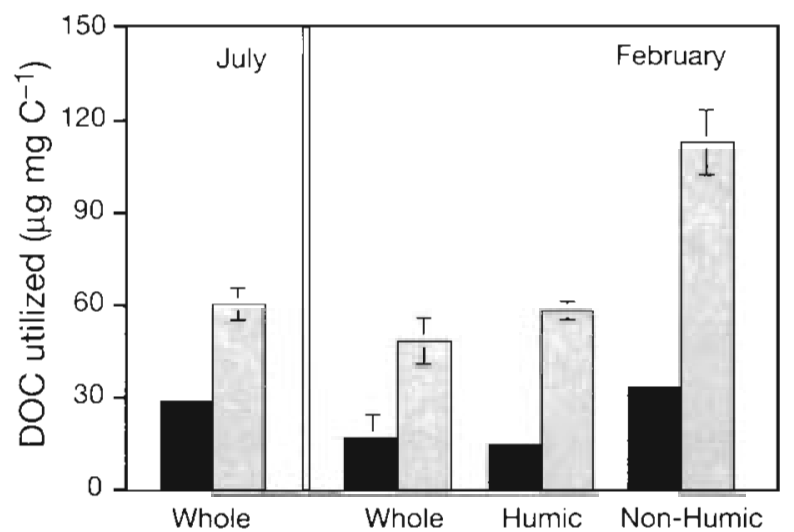

Fig. 3. Bacterial carbon utilization normalized to initial DOC concentration in non-irradiated (dark bars) and irradiated (light bars) treatments amended with inorganic nutrients ( $\mathrm{N}$ and $\mathrm{P}$ ). $\mathrm{n}=2, \pm 1 \mathrm{SD}$

whole DOM by an additional 31 (July) and 29 (February) $\mu \mathrm{g} \mathrm{C} \mathrm{mg} \mathrm{DOC}{ }^{-1}$, which more than doubled the rate of carbon utilization in both cases. Non-humic compounds were more bioavailable per unit weight of carbon than humic substances (33 vs $14 \mu \mathrm{g} \mathrm{C} \mathrm{mg}$ $\mathrm{DOC}^{-1}$ ). Irradiation resulted in the utilization of an additional 80 and $44 \mu \mathrm{g} \mathrm{C} \mathrm{mg} \mathrm{DOC}{ }^{-1}$ for these 2 fractions (Fig. 3). Bacterial utilization of irradiated whole DOM was estimated at 6.0 and $4.8 \%$ (July and February sample) of the DOC pool compared to 3.0 and $1.7 \%$ for non-irradiated DOM (during the $4 \mathrm{~d}$ experiments). Irradiation increased utilization from 3.3 to $11.0 \%$ for non-humic compounds and from 1.5 to $5.8 \%$ for humic substances (February sample).

\section{DOC concentrations and absorptivity coefficients}

DOC concentrations in the surface waters of the Okefenokee Swamp are typically quite high, as was found for the July (47.8 $\mathrm{mg} \mathrm{C}^{-1}$ ) and February (39.7 $\mathrm{mg} \mathrm{C}^{-1}$ ) samples. Humic substances constituted $79 \%$ of the recovered DOM in the February sample (31.4 $\mathrm{mg} \mathrm{C} \mathrm{l}^{-1}$ ), and non-humic compounds constituted $21 \%\left(8.3 \mathrm{mg} \mathrm{C} \mathrm{l}^{-1}\right)$.

Light absorption was likewise high in these samples. Absorptivity coefficients for the July and February whole water samples were 72.8 and $92.3 \mathrm{~m}^{-1}$, respectively. Absorptivity coefficients for the isolated fractions from the February sample were $56.3 \mathrm{~m}^{-1}$ (humic substances) and $9.1 \mathrm{~m}^{-1}$ (non-humic compounds). The sum of the absorptivity coefficients of the 2 February fractions accounted for $75 \%$ of the absorptivity measured in the whole water sample, indicating that not all the light-absorbing compounds were recovered during the fractionation scheme. Hydrophobic neutral compounds, a fraction of the DOM which requires an 
organic solvent for elution from the XAD-8 resin (Leenheer 1981), is a possible reservoir of the missing absorptivity. Alternatively, changes in $\mathrm{pH}$ and trace metal concentration associated with the fractionation procedure may have altered absorption characteristics of the DOM.

\section{DISCUSSION}

Exposure of DOM from this acidic freshwater wetland to sunlight considerably enhanced bacterial growth, indicating photochemical conversion of DOM into more biologically labile forms. Based on previous studies, it is expected that the biologically labile compounds fueling increased bacterial production are primarily low molecular weight (MW) carbonyl compounds (<200 MW) (Kieber et al. 1990, Wetzel et al. 1995, Moran \& Zepp 1997) as well as humic substances that have been modified via photochemical processes into more biologically labile forms (Miller \& Moran 1997). Carbon monoxide is another quantitatively important photoproduct of Okefenokee Swamp DOM (Valentine \& Zepp 1993), although its role as a bacterial substrate in natural waters is not well understood (Kraffzik \& Conrad 1991, Zuo \& Jones 1995).

For 2 of the DOM treatments in this study (whole DOM and non-humic compounds), incubations were carried out in the natural Okefenokee Swamp water matrix (as opposed to the distilled water matrix used to dilute the humic substances concentrate). In both of these cases, there was little evidence of nutrient addition effects in the non-irradiated treatments, indicating carbon limitation of the heterotrophic bacteria in these particular samples. In the irradiated treatments, the conversion of recalcitrant carbon into more available forms increased bacterial carbon utilization by up to 3-fold. In several cases, greater bacterial utilization in treatments with added $P$ than in those without indicated phosphorus limitation following irradiation. Thus despite very high dissolved carbon concentrations, bacterial turnover of DOC is likely to be carbon limited in this wetland environment, although the photodegradation of DOC to more biologically available forms could potentially shift surface waters to P-limited conditions.

For the February sample, we compared the relative importance of humic vs non-humic fractions of DOM as a source of biologically labile photoproducts. Differences in bacterial yield between irradiated and non-irradiated treatments (under nutrient sufficient conditions) were used to calculate photoproduction of labile organic matter (Table 1). Corrections for differences in the extent of light screening during the irradiations indicated that rates of photoproduct formation in the humic substances flasks were depressed to $25 \%$ of the expected rates if the entire flask had been exposed to fullsunlight conditions; rates of photoproduct formation were $75 \%$ of those expected under full-sunlight conditions in the non-humic fraction (Table 1). To compare the efficiency of production of biologically labile photoproducts from the 2 fractions, the non-humic values were adjusted downward to match the screening effect in the humic substances flask. These corrected values (Table 1) were divided by the time of exposure $(7 \mathrm{~h}$ ) and then normalized to the absorptivity of each sample (i.e. divided by the average $a_{350}$, expressed in units of $\mathrm{m}^{-1}$ ) (Miller \& Zepp 1995). These normalized production rates were approximately equal for the 2 fractions, calculated as $3.2 \times 10^{-3} \mathrm{mg} \mathrm{C} \mathrm{m} \mathrm{l} \mathrm{l}^{-1} \mathrm{~h}^{-1}$ (humic substances) and $3.0 \times 10^{-3} \mathrm{mg} \mathrm{C} \mathrm{m} \mathrm{l}^{-1} \mathrm{~h}^{-1}$ (non-humic compounds).

Although absorbance-normalized rates of photoproduction of labile organic matter from the 2 fractions are equivalent (i.e. rates normalized to the number of photons absorbed), calculated in situ rates in an unfractionated water sample are not. Comparison of the absorptivity coefficients $\left(a_{350}\right)$ between the fractions (measured when the fractions were isolated from each other but at natural concentration) indicates that humic substances would absorb 6 -fold more light $\{86 \%$ of the total) than non-humic compounds (14\% of the total) when the fractions were recombined (based on $a_{350}$ values of 56.3 vs $9.1 \mathrm{~m}^{-1}$ ). Thus given equivalent absorbance-normalized production rates, humic substances would play a greater role as a source of labile photoproducts (by approximately 6 -fold) than would non-humic compounds.

Table 1. Bacterial utilization of DOM collected in February 1996 from the Okefenokee Swamp (Georgia, USA) calculated from biomass accumulation in bacterial bioassays under nutrient sufficient conditions. Labile photoproducts are calculated as the difference between bacterial biomass yields in irradiated and non-irradiated treatments. Corrected values are calculated by accounting for greater light screening in the humic substances fraction during irradiation Units are $\mathrm{mg} \mathrm{Cl} \mathrm{l}^{-1}$

\begin{tabular}{|lcccc|}
\hline DOM fraction & $\begin{array}{c}\text { Biomass yield } \\
\text { non-irradiated }\end{array}$ & $\begin{array}{c}\text { Biomass yield } \\
\text { irradiated }\end{array}$ & $\begin{array}{c}\text { Labile } \\
\text { photoproducts }\end{array}$ & $\begin{array}{c}\text { Corrected labile } \\
\text { photoproducts }\end{array}$ \\
\hline $\begin{array}{l}\text { Whole DOM } \\
\text { Humic substances }\end{array}$ & 0.68 & 1.85 & 1.17 & \\
$\begin{array}{l}\text { Non-humic } \\
\text { compounds }\end{array}$ & 0.28 & 1.68 & 1.24 & 1.24 \\
\hline
\end{tabular}


The importance of photodegradative processes in the turnover of Okefenokee Swamp DOM will be controlled by exposure of surface waters to natural sunlight, the depth of light penetration into the water column, and the residence time of DOM in the system. Because of the dark color and high absorptivity of Okefenokee water, wavelengths most effective in producing DOM photoproducts (primarily UVA and UVB) will penetrate only a few centimeters into the surface water (Moran \& Zepp 1997). If only the top $3 \mathrm{~cm}$ of the water column, which averages $61 \mathrm{~cm}$ in depth (Rykiel 1984), is exposed to near-surface light intensities, about $5 \%$ of the Okefenokee water column is subject to photodegradative processes at any one time. Given an average residence time of 130 d (Rykiel 1984), cloud cover approximately $20 \%$ of the time, and $7.6 \mathrm{~h}$ of noontime sun per day (Miller \& Zepp 1995), DOM will be exposed to about 50 h of UVA and UVB irradiation (at noontime intensity) during its residence time in the Okefenokee Swamp. Thus in situ photochemical effects on biodegradation during the residence time of DOM are likely to be of greater magnitude than that which was measured in this study (based on only $7 \mathrm{~h}$ of noontime irradiation).

Photochemical modification is likely to be an important mechanism of DOM turnover in other shallow aquatic systems as well, given that biodegradation of both humic and non-humic fractions of DOM can be significantly enhanced by even fairly short exposures to natural sunlight. While humic substances were found to be the primary source of biologically labile photoproducts in a system in which these compounds dominate the DOM pool (accounting for $80 \%$ of the total), the non-humic component of DOM was equally reactive on an absorbancenormalized basis. Similar high efficiencies of formation of 2 other DOM photoproducts, carbon monoxide and dissolved inorganic carbon, from 'non-humic' organic matter have been reported recently (Zepp et al. 1995). Thus in lakes, rivers, coastal oceans, and other aquatic environments where humic substances constitute only 15 to $40 \%$ of the DOM pool (Thurman 1985), non-humic compounds may play a more important role as a source of biologically labile photoproducts.

Acknowledgements. We thank E. Sheppard for technical assistance, and M. Skippy Reeves and Sara B. Aicher of the U.S. Fish and Wildlife Service at the Okefenokee National Wildlife Refuge for facilitating access to field sites. R. Zepp generously allowed use of his laboratory equipment and provided help with light exposure calculations; W. Miller and $\mathrm{H}$. Gao gave us suggestions on methods and data analysis; and 3 anonymous reviewers made helpful comments on an earlier version of this manuscript. This research was funded by National Science Foundation grant DEB 9222479.

\section{LITERATURE CITED}

Aiken GR (1985) Isolation and concentration techniques for aquatic humic substances. In: Aiken GR, McKnight DM, Wershaw RL, MacCarthy P (eds) Humic substances in soil, sediment and water. Wiley, Chichester, p 363-385

Aiken GR, McKnight DM, Thorn KA, Thurman EM (1992) Isolation of hydrophilic organic acids from water using nonionic macroporous resins. Org Geochem 18:567-573

Allard B, Borén H, Pattersson C, Zhang G (1994) Degradation of humic substances by UV irradiation. Environ Int 20:97-101

Amador JA, Alexander M, Zika RG (1989) Sequential photochemical and microbial degradation of organic molecules bound to humic acid. Appl Environ Microbiol 55:2843-2849

Azam F, Hodson RE (1977) Dissolved ATP in the sea and its utilization by marine bacteria. Nature 267:696-698

Backlund P (1992) Degradation of aquatic humic material by ultraviolet light. Chemosphere 25:1869-1878

Bano N, Moran MA, Hodson RE (1997) Bacterial utilization of dissolved humic substances from a freshwater swamp. Aquat Microb Ecol 12:233-238

Bratbak G, Dundas I (1984) Bacterial dry matter content and biomass estimations. Appl Environ Microbiol 48:755-757

Bushaw KL, Zepp RG, Tarr MA, Schulz-Jander D, Bourbonniere RA, Hodson RE, Miller WL, Bronk DA, Moran MA (1996) Photochemical release of biologically available nitrogen from aquatic dissolved organic matter. Nature 381:404-407

De Haan H (1993) Solar UV-light penetration and photodegradation of humic substances in peaty lake water Limnol Oceanogr 38:1072-1076

Hobbie JE, Daley RJ, Jasper S (1977) Use of Nuclepore filters for counting bacteria by fluorescence microscopy. Appl Environ Microbiol 33:1225-1228

Kieber DJ, McDaniel J, Mopper K (1989) Photo-chemical source of biological substrates in sea water: implications for carbon cycling. Nature 353:60-62

Kieber RJ, Zhou X, Mopper K (1990) Formation of carbonyl compounds from UV-induced photodegradation of humic substances in natural waters: fate of riverine carbon in the sea. Limnol Oceanogr 35:1503-1515

Kirchman DL, K'nees E, Hodson R (1985) Leucine incorporation and its potential as a measure of protein synthesis by bacteria in natural aquatic systems. Appl Environ Microbiol 49:599-607

Kirk JTO (1994) Optics of UV-B radiation in natural waters. Ergebn Limnol 42:1-16

Kraftzik B, Conrad R (1991) Thymidine incorporation into lake water bacterioplankton and pure cultures of chemolithotrophic $\left(\mathrm{CO}, \mathrm{H}_{2}\right)$ and methanotrophic bacteria. FEMS Microbiol Ecol 23:7-14

Leenheer JA (1981) Comprehensive approach to preparative isolation and fractionation of dissolved organic carbon from natural waters and wastewaters. Environ Sci Technol 15:578-587

Lindell JM, Granéli WH, Tranvik LJ (1996) Effects of sunlight on bacterial growth in lakes of different humic content. Aquat Microb Ecol 11:135-141

Miller WL (1998) Effects of UV radiation on aquatic humus: photochemical principles and experimental considerations. In: Hessen DO, Tranvik L (eds) Aquatic humic substances: ecology and biogeochemistry. Springer Verlag, Berlin, p 125-143

Miller WL, Moran MA (1997) Interaction of photochemical and microbial processes in the degradation of refractory dissolved organic matter from a coastal marine environment. Limnol Oceanogr 42:1317-1324 
Miller WL, Zepp RG (1995) Photochemical production of dissolved inorganic carbon from terrestrial organic matter: significance to the oceanic organic carbon cycle. Geophys Res Lett 22:417-420

Moran MA, Hodson RE (1990) Bacterial production on humic and non-humic components of dissolved organic carbon. Limnol Oceanogr 35:1744-1756

Moran MA, Zepp RG (1997) Role of photoreactions in the formation of biologically labile compounds from dissolved organic matter. Limnol Oceanogr 42:1307-1316

Rykiel EJ (1984) General hydrology and mineral budgets for Okefenokee Swamp; ecological significance. In: Cohen $A D$, Casagrande DJ, Andrejko $M J G$, Best R (eds) The Okefenokee Swamp: its natural history, geology, and geochemistry. Wetland Surveys, Los Alamos, p 212-228

Simon M, Azam F (1989) Protein content and protein synthesis rates of planktonic marine bacteria. Mar Ecol Prog Ser 51:201-213

Smith DC, Azam F (1993) A simple, economical method for measuring bacterial protein synthesis rates in seawater using ${ }^{3} \mathrm{H}$-leucine. Mar Microb Food Webs 6:107-114

Strome DJ, Miller MC (1978) Photolytic changes in dissolved humic substances. Int Ver Theor Angew Limnol Verh 20 1248-1254

Thurman EM (1985) Organic geochemistry of natural waters. Martinus Nijhoff/Dr W Junk, Boston

Editorial responsibility: Farooq Azam,

La Jolla, California, USA
Tranvik LJ (1988) Availability of dissolved organic carbon for planktonic bacteria in oligotrophic lakes of different humic content. Microb Ecol 16:311-322

Valentine RL, Zepp RG (1993) Formation of carbon monoxide from the photodegradation of terrestrial dissolved organic carbon in natural waters. Environ Sci Technol 27: $409-412$

Wetzel RG, Hatcher PG, Bianchi TS (1995) Natural photolysis by ultraviolet irradiance of recalcitrant dissolved organic matter to simple substrates for rapid bacterial metabolism. Limnol Oceanogr 40:1369-1380

Wright RT, Hobbie JE (1966) Use of glucose and acetate by bacteria and algae in aquatic ecosystems. Ecology 47 : $447-464$

Zepp RG (1982) Experimental approaches to environmental photochemistry. In: Hutzinger $\mathrm{BO}$ (ed) The handbook of environmental chemistry, Vol 2/PartB. Springer-Verlag. Berlin, p 19-41

Zepp RG, Miller WL, Bourbonniere RA, Tarr M (1995) Interactions of changing solar ultraviolet radiation on organicmatter pholooxidations in northern peatlands. Abstr Pap Am Chem Soc 210(1): \#69 ENVR

Zuo Y, Jones RD (1995) Formation of carbon monoxide by photolysis of dissolved marine organic material and its significance in the carbon cycling of the oceans. Naturwissenschaften $82: 474-474$

Submitted: September 5, 1997; Accepted: June 8, 1998 proofs received from author(s): September 29, 1998 